\title{
Context-Specific and Firm-Specific Factors and Their Effect on Banking Credit Policies in Post-Unification Southern Italy: A Case Study
}

\author{
Puntillo Pina ${ }^{1}$, Rubino Franco Ernesto ${ }^{1} \&$ Cambrea Domenico Rocco ${ }^{1}$ \\ ${ }^{1}$ Department of Business Administration and Law, University of Calabria, Italy \\ Correspondence: Pina Puntillo, Department of Business Economics, University of Calabria, Italy. E-mail: \\ pina.puntillo@unical.it
}

Received: December 12, 2017

Accepted: May 21, 2018

Online Published: June 30, 2018

doi:10.5539/ijbm.v13n8p257

URL: https://doi.org/10.5539/ijbm.v13n8p257

\begin{abstract}
The paper presents a case study based on the credit policies of a southern Italian bank, named "Cassa di Risparmio di Calabria", which operated between 1861 and 1998. We opted to investigate the role of "Cassa di Risparmio di Calabria" because historical researchers considered it, in the years following the unification process of Italy, the most important local bank in southern of the country. In order to analyze the credit policies of the Cassa di Risparmio di Calabria, we employed an interdisciplinary approach, using Canergie and Napier's framework, which allows us to investigate both contextual and firm-specific factors that affected the way in which the firm adopted its credit policies emerging from bookkeeping.

To address the research question of the paper a case study has been used. This methodology fits very well with the purpose of this paper because it offers the possibility of investigating a firm's policies from a practical rather than a theoretical point of view, through the exploration of a complex phenomenon in a specific context.. The use of a case study provides scholars a rich source of data from a real setting with the aim to deepen the understanding of the investigated phenomena.

To address the research question, we used moreover archival sources, both accounting and non-accounting documents, as well to several statutes and notary protocols, old books, journal and ledgers. The findings highlight the important part of the local bank in contributing to the economic development of the area and its role in improving the human conditions within the territories under its jurisdiction, as well as the great importance to socio-educational investments. Diversely, from the qualitative analyses it emerges the marginal support to the manufacturing and commercial activities. The article contributes to enlarging the knowledge of the functioning of the credit sector in southern Italy after unification. The originality of the article lies in the use of an interdisciplinary approach, specifically the Canergie and Napier framework, to analyze credit policies of a bank.
\end{abstract}

Keywords: credit policies, Southern Italy, banking sector

\section{Introduction}

Hopwood (1983) advocated the study of accounting "in the contexts in which it operates". Rather than "detaching accounting from its organizational setting" (Hopwood, 1983, p. 288), historical and contemporary accounting researchers were effectively encouraged to view accounting not as an end in itself but as a means to an end. It is enacted to serve specific purposes. Accounting is indeed an integral part of governance, accountability, sustainability and other controlling/monitoring processes or regimes, however, described in the past. Investigating the story behind the accounts within the contexts in which that book was prepared offers at least potentially more interest and significance under the conception of accounting as social practice (Canergie \& Napier, 2012, Canergie, 2014, p. 1245). Recognizing that environmental factors assume importance in explaining both contemporary and historical accounting practice, Carnegie called on accounting historians to examine culture as one of a range of key variables to assist in explaining accounting practices in their local, time-specific contexts.

Addressing the research question of the paper we decide to complement the contextual approach derived from Hopwood (1983) and Canergie and Napier's framework (2012), who point out the role played by the context, the actors and the resources owned, in deploying social practices. 
Canergie and Napier (2012) believe that accounting history is enhanced by locating our narratives within an understanding of the specific context in which the object of our research emerges and operates that we all write, implicitly if not explicitly, to a paradigm.

Also Mathias (1993, p. 271) believed accounting history: "Should gain from being related to context, part and parcel of the wider operation of business; accounting techniques being diffused and developed in response to the demands of business and other professional users as much as advancing autonomously under their own internal professional momentum". We believe that social practice such as credit policies emerging from bookkeeping are a product of both context-specific (external) and firm-specific (internal) factors. The aim of this paper is to investigate the role played by the two categories of drivers in explaining the credit policies of the "Cassa di Risparmio di Calabria" in post-unification southern Italy. Bearing in mind Canergie and Napier's framework, we adapt this background to our research approach.

In order to achieve the main research objective, we posit the following research question:

RQ: Were the credit policies of the "Cassa di Risparmio di Calabria" in southern Italy after unification affected mostly by external (contex- specific) factors or instead by internal (firm-specific) factors?

\section{Method}

To address the research question of the paper a case study has been used. This methodology fits very well with the purpose of this paper because it offers the possibility of investigating a firm's policies from a practical rather than a theoretical point of view, through the exploration of a complex phenomenon in a specific context.. The use of a case study provides scholars a rich source of data from a real setting with the aim to deepen the understanding of the investigated phenomena (Yin, 2003).

Another methodological issue concerned the choice of whether to draw a horizontal or vertical history of the phenomenon under investigation (Kragh \& Fanti, 1990). In the first case, we study the evolution in time of the argument, in the second case, we adopt an interdisciplinary perspective where the object under investigation is treated as an element of the broader socio-cultural context of the period, not only cannot it be detached from others of the same time, but rather together with them helps to define the meaning of that historical moment (Servalli, 2007, pp. 59-77). His paper has drawn a vertical history of the phenomenon under study.

Next, as regards the prospective in which the scholar must stand in addressing the analysis, the choice is between a synchronic and a diachronic approach. In this paper, we adopted a "synchronous" concept of historical research ("the science of the past is studied in the light of the knowledge we possess today, with a view to understanding its further development") whereas in the "diachronic" approach (the science of the past is studied "in the light of situations and concepts of the real", neglecting all other subsequent events) (Amaduzzi, 2001, p. 15)

The "Cassa di Risparmio di Calabria" (hereafter Cassa) was selected because it presents many features we judge interesting as a case study. The bank originated in the second half of 1800 during the last phase of the Bourbon government, and is included as intimately connected with the history of the development of Calabria.

The socio-economic environment of Calabria, a vassal region of the Bourbon regime, at the time of the birth of the Kingdom of Italy, showed clear signs of backwardness. The Cassa di Risparmio of Calabria was established September 24, 1861 to alleviate the fate of the Calabrian and to perform work of moralization in lending, serving as a catalyst in the field of loans with the aim of placing a limit on the usurious practices flourishing at the time, and achieving savings primarily as a tool of social education and moral and intellectual elevation For more than a century the bank fulfilled the role of engine of socio-economic progress, until the post-war reconstruction of World War II, always characterized, however, by a social connotation and moral solidarity. The events that led to the institution of the Casse di Risparmio, in the years around the middle of the nineteenth century, are to be analyzed in the light of the support function that these institutions have played in the local economy until the last century. The Casse di Risparmio were merged into larger banks in the last decades of the twentieth century The events that accompanied the incorporation of local banks in larger entities frequently resulted in the loss and dispersion of material essential to the reconstruction of the recent past; for this is all the more necessary to define their role now that the documentation relating to them in danger of disappearing.

Owing the nature of the paper, document analysis (Bowen, 2009) was the main tool to assemble the accounting data (the primary source) needed to provide evidence of the research question.

In the first phase, archival sources (accounting and non-accounting) have been used for this purpose, as well as statutes and notary protocols. We had a look at all Cassa's accounting documents, while in a second phase we studied the internal and external factors, which had an impact on the credit policy of the bank in the light of our Canergie and Napier's framework. In doing so, we followed an interpretative approach (Ryan et al., 2002). 


\section{Analyzing Cassa Di Risparmio Di Calabria's Context- Specific Factors}

The movement at the base of the institution of the Casse di Risparmio can be defined philanthropic, because the substrate of solidarity and support that connotes differentiates them from other credit companies born for-profit purposes (Cardinali, 1972). An accredited thesis infers the Casse di Risparmio by budding from pawnbroking, born in the 15th century in Italy by the preaching of the Franciscans (Cardinali, 1969).

The existing functions of these banks were everywhere characterized by the local savings deposits, enough to be noted as "daughters of the place and daughters of the time" (Titta, 1969). Their universal order was the local gathering deposits, starting from the lower classes, and their use to be conservative to protect depositors. The main feature of these banks was the total absence of a philosophy of profit-making, and the obligation to allocate a quota of $50 \%$ of any income to charitable donations. Being entities in the territorial jurisdiction boxes were investing only in collecting territories from all social strata, features summarized in the following statement "The Casse di Risparmio represent the democratic expression in the lending ground" (Giordano dell'Amore, 1953).

Cassa di Calabria was founded in Cosenza saving with provincial deliberation September 24, 1861, with the funds of the Casse Agrarian of Cosenza and Rossano established by Ferdinand II the Bourbon in 1853. It takes effect August 2, 1862

The Cassa was created as a tool for education savings and moral and intellectual elevation, as well as material (Centenario, 1961), and interprets the banking function as a moral obligation of mutuality and Christian solidarity (Cardinali, 1953). Article 3 of the Statute reads: "The main purpose of this institution is to promote the class of workers, which is provided the means to put in a safe and profitable deposit small amounts that gradually were able to conserve, which gradually accumulated. They would place them in a position to cope, not only where they could be subjected to random accidents, but also improve your status. "

The institute encountered considerable difficulties in the early years, mainly because of the economic conditions of the local populations, which made difficult the formation of savings.

These difficulties were also a result of poor knowledge of the purpose and utility of the banks, because of which the Cassa invested a lot in propaganda.

The first investors were the maids and small savers orphanage. The first went on Monday and Saturday of each week to bring their savings at the office of the Fund, exactly in the house of Mr Luigi Trocini, Palazzo Campagna, which delivered to each booklet to cost 15 cents. The maids when they needed money, they returned with the record book on Tuesday or Friday, and the interests also handed their case.

It should also consider that the bank's activity was confined in very limited schemes and especially that the administration of the same mingled with that of the province, reserving the latter also the resolutions concerning the banking business, such as raising activities and use of funds (Centenario, 1961). The assessment of the Cassa investments therefore received due importance and weighting and especially speed, being on the agenda of the advice of the Province a host of other materials of different nature.

The deputation met twice a month, so that he could not always treat all points on the agenda. For this reason, it expressed the need to establish another administrative body. On 29 May 1880 the deputation deliberated urgent setting up of a Commission Administrator of the Cassa, which was part of the director, who took on the task of taking the measures previously under the responsibility of the deputation. This organ decreed in law and in fact the autonomy of the same from the Provincial Deputation.

Meanwhile he took shape the debate on the reform of the legal structure of the Casse di Risparmio, which led to the adoption in 1888 of the law that recognized the character of autonomous Moral Bodies, which have the purpose of the public good but not that of the profit, and to strive for education of the masses to security.

At the end of the nineteenth century the Bank increased the mass of the deposits proceeded to a modernization of internal services institution operating a prudent management of the collected savings (General Report, 1901). It should be noted as of now as the Chairman of the Board of Directors of the time, Cav. in the report of the 1900 balance sheet on the large inflow of deposits to the sharply pointed Case: "There are millions and millions who are fleeing to agriculture and local industry, ... and take refuge at the Cassa for a kind of fear reckless and harmful. The phenomenon is flattering in our dealings with the public and is proof of unlimited confidence that enjoys our institution; but what is he now worrying sign for the public wealth and what repercussion suffers from this fact, that agriculture should be for this population the only source of well-being and prosperity!".

In fact, we can observe from now, as the activities of the Cassa was not addressed to the rehabilitation and development of the local economy, in fact, the lending business was very modest. While in almost all other 
regions rose large manufacturing complexes, took place the reclamation of uncultivated patches, they built the most important road and rail transport routes, and the Casse di Risparmio became protagonists of this evolution, changing from philanthropic institutions broad economic action centers, Calabria suffered scarcely of this evolutionary movement. Even become a lender the Cassa di Risparmio di Calabria limited his activities to raise funds and to a cautious investment of the same, just to ensure the absolute safety of savings collected (Centenario, 1961).

It was that persecutes almost exclusively the function of public usefulness of the institution, geared mostly to education to savings of the Calabrian people, while the lending business had also a social purpose, in fact, were financed mainly public works, such as the works rail of the province, municipal roads, irrigation works, etc .. it was expressly required by statute and loans should have security requirements and ready and easy realizable, and that constituted prudent provisioning for the same purpose.

Overcome the difficult years of the First World War began a territorial expansion. In 1922, the Bank opened its first dependencies in Rossano of district capitals, Castrovillari and Paola and between 1926 and 1928 another 17 branches, all in the province of Cosenza, becoming the local institute financially and organically more powerful southern Italy. In 1930 the Cassa absorbed the Banca Cattolica di Calabria and the Calabria Commercial Bank, continuing its lending activities in particular in agriculture and public works, in addition to participation in funding required by particular circumstances such as the Ethiopian war. In 1937, the Bank occupied the 42th place among the Italian sisters in the collection of savings exceeding 77 million lire of managed capital, and became the largest credit institution in the continental South after the Bank of Naples. The figure is particularly important when you consider that the institute was operating in one of the most depressed areas of the country where the per capita income was seven times lower than that of the most economically advanced regions. In 1960 it will reach 10 in the classification above, and 110 branches throughout the region.

\section{Analyzing Cassa Di Risparmio Di Calabria's Firm- Specific Factors}

Over the analysis period ranging from 1938 to 1960 , the Institute enjoyed the full trust and unconditional acceptance on the part of investors, increasing the deposits by 611 times, while the other Italian banks recorded an increase of 185 times. These data represent the result of a capillary penetration aimed mainly at an action for education in the fundamental principles of security and savings, including the important message that the money collected was still employed in the local economy. It was in fact a constant policy of the bank to inform the public of the financial public works, its merits and moral and material benefits that arose from the practice of savings. The action of propaganda to young people had been particularly intense, with interventions in favor of youth associations, sports, distributing school supplies, educational equipment, setting up the world's savings day with the participation of the authorities but also of the schools, not failing to inform on such occasions the goals and beneficial actions of the case. According to its statutes, the Bank undertook charitable activities for needy categories, several actions included the financing of kindergartens, orphanages, charitable funds and school, hospices, hospitals, municipal infirmaries, and other initiatives of philanthropic or cultural aid.

The Cassa is also characterized by a policy of redistribution of capital in the same collection areas. The role of the regional economic engine was developed mainly with reference to the agricultural sector. A remarkable fact was the support given to the agricultural credit operations of improvement, making loans for the purchase of agricultural machinery, loans for construction of irrigation systems and rural buildings, mortgages for plant and development of forestry livestock farming companies, loans to agricultural consortiums, etc. (Polimeno, 1958).

There was also intense activity in favor of the public authorities and with mortgages with cash advances. Instead the financial support to the industrial sector appears residual.

Until the 60's of last century, therefore, the Cassa di Risparmio of Calabria was identified as a local financial institution, with a special vocation, which is to educate local populations to savings intended just as a value and a lifestyle to follow, and at the same time, as an entity with an ethical and non-entrepreneurial finality.

Meanwhile, at the national level an interesting debate started on the role of the Casse di Risparmio in the economy, saving, focusing on the vector role of the general improvement in economic and social conditions that they had to start to play, especially in the most economically backward geographical areas (Antoniozzi, Conti, 1955).

These concepts found initial acceptance by the Cassa di Risparmio di Calabria leading the banking business expansion both in Puglia and in Basilicata. Particularly, in the latter region the activities of both deposits and use of the funds were so significant that in 1959 the institute changed its name again to Cassa di Risparmio di Calabria and Lucania. 
The Cassa di Risparmio was founded with the aim of offering a real contribution to overcoming social and economic backwardness of the time in Calabria.

As observed by Padula in the newspaper "The Bruzio" of 1864 the drive to preserve and make fruitful the hard-earned savings realized not only the sense of thrift but also the socio-economic advancement of the individual, even more so under the collective utility aspect and popular purposes in order to bring effective remedies to bear on the social evil that grips the have-nots. The problem of usury was strongly present in pre-unification Calabria, also the result of the lack of credit institutions on the ground.

The Cassa di Risparmio of Calabria pursued objectives of public interest with the utmost effectiveness, playing a leading role in the financing of social investments of public utility in the province first and then at a regional level, directing these initiatives using the savings collected for the most part by families. Equally important is the beneficial activity countering usury had for the lower social classes. All investment transactions were still characterized by a very low degree of risk in the interests of absolute caution to protect depositors. The large mass of deposits that the bank raised steadily over the years was the fruit of the Education Savings philosophy carried out in a very backward area, both from an economic and a social and cultural point of view (Dell 'Amore, 1953).

Moreover, the lack of profit motive for the lack of shareholders to remunerate amplified the ability to financially support the local economy thanks to the attraction which stemmed from lending rates generally lower than those of other commercial banks applied by the Cassa. However, in retrospect comprehensive analysis on the policy followed by the Cassa at least until the sixties of the last century shows a tendency towards hoarding which effectively took away a huge money supply to useful investments (Acciaro, 1960).

The annual increase in deposits was the most meaningful measurement of the capacity of the administrators of the Cassa. Moreover, the absence of a profit motive, in conjunction with the legal and statutory obligation to donate the profit in whatever form to charitable donations pushed administrators to be more cautious in the selection of loans (Dell'Amore, 1975).

The historiography of operational formation of the institute reports demonstrates the intense activity carried out by the institute, and also the evolutionary profile of the same, otherwise detectable view of the deficiencies of the Calabrian Banking Statistics. The Cassa, in the historical perspective that embraces the period from 1862 to 1906 is characterized by the incredible increase in deposits. From 14 deposit books in 1862 the number grew to 2,806 in 1884 , to 13,180 in 1906 and to 18,935 in 1939. Since 1940 the savings deposits are flanked deposits, c/c of correspondence, valuable to promote, sustain and enhance the development and expansion of the regional economic fabric. The reports of lending operations (derived from statements) can analyze the credit policy of the Bank and provides an analytical framework that can be set chronologically as follows:

1. 1862-1881 Cassa work goes into a low-grade development environment that determines a go 'activities use funds in securities with certain achievements (which still resulted in the export of Cassa's outside the territory where the institution operates), given the lack of prospects to local productive sectors; the financing activities were mainly directed towards the Moral Bodies witnessing the active contribution made by Cosentino banking association (for the construction of infrastructure, connoting the public character of the praiseworthy Cassa ).

2. 1882-1920 the Cassa starts to employ the means collected in entrepreneurship also for the collective interest, through loans secured by mortgages, unsecured loans to individuals, use in industrial and commercial titles, discounts bills of exchange, etc.

3. 1921-1939 political and economic events of the period (bank failures that followed the end of the First World War, advent of the fascist regime, deflation of 1925, etc.) determines an irregular trend of Cassa assets which continues nevertheless in its policy of territorial expansion.

4. 1940-1947 there is a revival of employment activities still mainly oriented towards the purchase of securities and loans to Moral bodies;

5. 1948-1990 the institution restructures the credit lines, including diversification of funded sectors (for example in 1966 a credit line of the hotel industry is activated, not present in the financial statements before then), but the investment in property titles remains the main activity.

6. 1990-1998 a period of great legal and organizational transformations, decreed by merging operations. In 1998, the Cassa, the Cassa di Risparmio of Puglia founded Bari in 1949 and the Cassa di Risparmio Salernitana founded in Salerno in 1956, come together to form the Carime Bank. On 29 June 2001 Carime joined the Banca Popolare Commercio e Industria. It experiences important stages of integration and reorganization to the entrance in the Banca Popolare Commercio Industria in 2001 and from 1 July 2003 it joined the Banking Group 
Banche Popolari Unite, BPU Banca. On 1 April 2007 Banca Carime becomes part of the UBI Group (Union of Italian banks) emerging from the merger of Banks between the BPU Banca and Banca Lombarda e Piemontese Group.

Below, the graphic representation of bankbooks, of bank deposits and unsecured liabilities during the whole period of life of the bank.

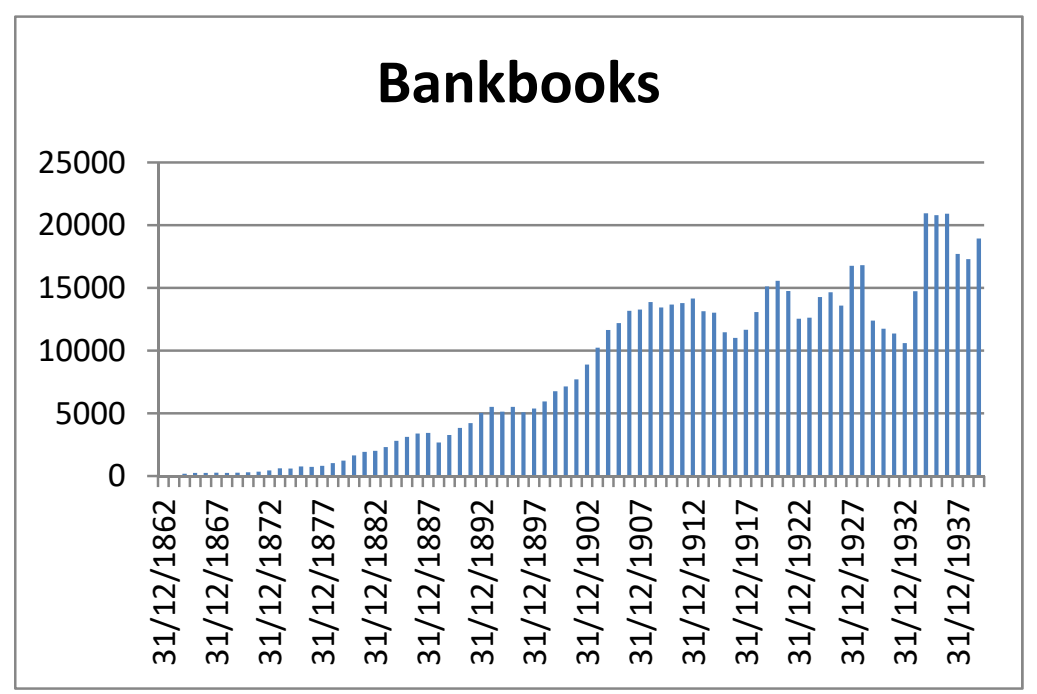

Figure 1. bankbooks in the period 1862-1939

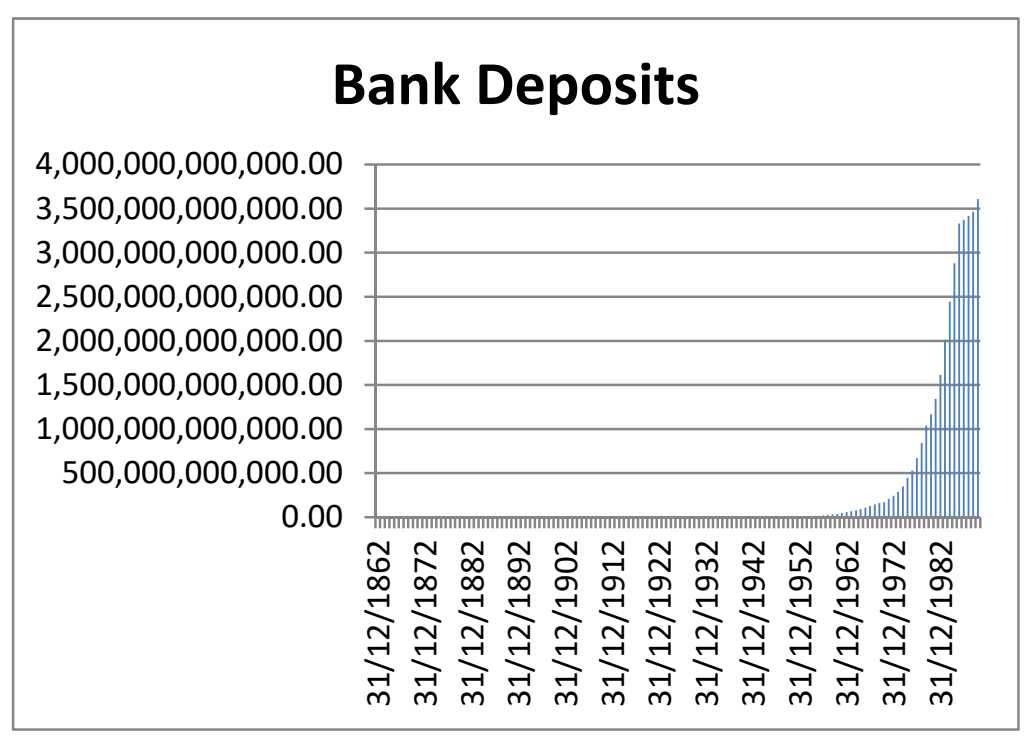

Figure 2. Bank deposits in the period 1862-1990 


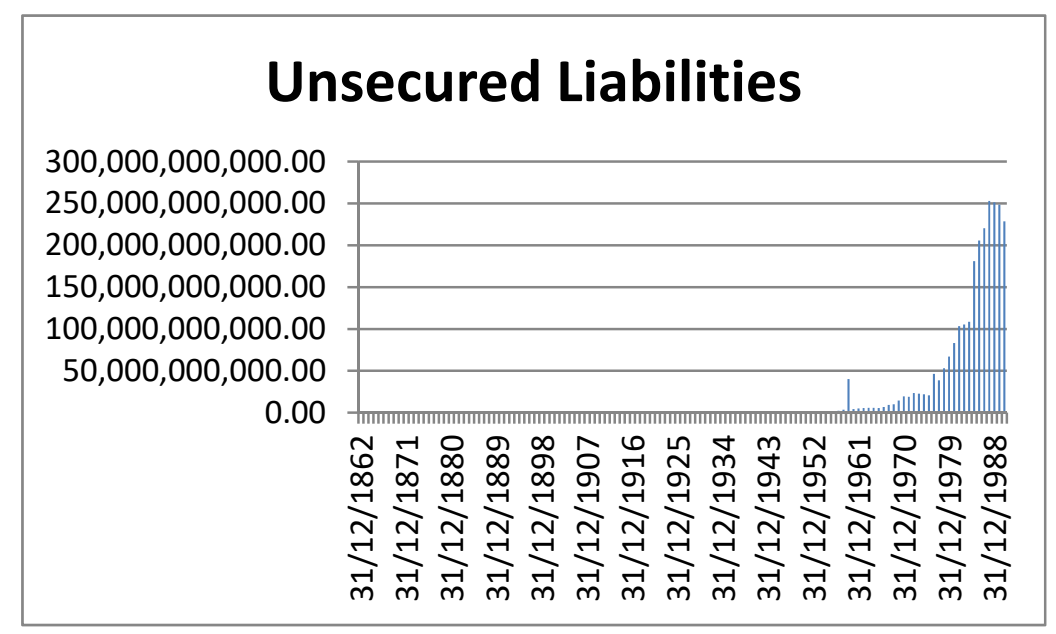

Figure 3. Unsecured liabilities in the period 1862-1990

Until the nineties, a policy to allocate budget surpluses to charitable works emerges from the financial statements, and that the operating activities have never been directed towards speculative investments. The case has always been characterized as the bank of the families first, implementing a sort of democratization of credit (i.e. granted not only to the wealthy families but also to the less well-off), and then as a reference point for local authorities and for the requirements financial cover running costs and for support for investment policies (Ruggieri, 1992).

In the 90's the case of facing the problems of the Single European Market, with the consequence of having to combine tradition and innovation, the latter arising from the need for internationalization of banking and efficiency to compete in new markets. The institute's fate will also depend on this finding.

\section{Context-Specific and Firm Specific Factors and Their Effects on Cassa Di Risparmio Di Calabria's Credit Policies}

The research question of the paper was to analyze which factor among the overall factors considered to affect the Cassa's credit policies had most effect, bearing in mind that, in our Canergie and Napier- like framework, factors are distinguished in external (context-specific) and internal (firm-specific) factors.

In the period in which Calabria was feeding industrialization, the regional institute for excellence in the fields and took inadequate amounts from the deposits collected to the productive sectors, devoting much more important amounts to the financing of public bodies. This credit policy was criticized by both Parliament and the doctrine. The former recommended to avoid the formation of excessive liquidity with investors or in the banking system and indicated in the postal savings the most important channel of capital inflows to the public sector, enabling the authorities to resort to the financial market in modest limits, seeing fulfilled its requests for funding from the Cassa Depositi e Prestiti. Dell'Amore noted that in poor regions such as Calabria the savings flow to post offices was subtracted to small and medium-sized enterprises, that these suffered from not having the ability to access the securities market. The role that the Cassa had to cover was that of an intermediary between the State and the entire South through a credit policy oriented enterprise support (Cedescal, 1965). Loans were instead dominated by investments in government securities, mortgage loans and financing of public works. The later quantification of the amounts to be allocated to investment transactions was particularly prudent. In the late '50s, the Interministerial Committee of the prescribed credit even at a $20 \%$ reserve Casse di Risparmio training increases fiduciary deposits. The Cassa was dismissive instead of the $43.2 \%$ increase in deposits, by subtracting a sum of around 30 billion lire to productive uses. The credit policy of the case is shown by the examples of the Documentation Centre and of Calabria (1965): for every thousand pounds of deposits the cash realized the following applications:

- 7 lire remained in cash;

- 180 lire were allocated to the activity of aid to employees for wages and transfers to municipalities and local authorities for advances

- 65 lire to agricultural credit;

- 61 lire in mortgage loans (purchase of houses, cooperatives and private); 
- 181 lire in ordinary portfolio (including consumer loans);

- 93 lire in current accounts guaranteed by promissory notes;

- 413 lire in government bonds and deposits with the Bank of Italy.

All considered, the firm's specific factors, in our opinion, strongly affected the Cassa's credit policies.

In conclusion, despite having an impressive savings potential available to the Cassa, it recoiled from the productive and reduced its business operations to a largely traditional and comfortable approach, with the result that large capital were not used fully.

Another problem is the organizational structure of branches with a number of employees much higher than other credit institutions, and with no modern operating mechanism and responsive to the needs of the times. In particular, the recruitment mechanisms were subject to logical party and not to organizational efficiency criteria (Cedesal, 1965). The lack of a research department that analyzes the macroeconomic indicators, the public administration programs, the region's economy, the performance and policies of the banks, made the myopic case from a strategic point of view, and certainly which have slowed the institution's modernization, and the consequential effects on the economy of the company and of the territory. The Cedesal (1965) In other words, the credit policy of the Cassa has not only been characterized by the almost total lack of risk, but it can also be observed how it escaped programming logic and has instead followed political or personalistic criteria.

The last question, but not the least important, is the creation of the Single European Market, which imposed a transformation of the banking system to address international competition adequately. Questions based on them have also affected the Cassas directing them towards an entrepreneurial character of banking intermediation, and combining journalistic issues with economic ones. In many cases, this has led to conjoint operations of transformation of the legal nature of the bodies, in the transfer of assets, merger with other credit institutions. The increase of the optimal size of companies can be viewed as a consequence of the creation of the Single European Market, which led to a progressive penetration of the markets and the affirmation of free movement of goods and services, prompting a large number of businesses to mergers to address broader and more competitive markets.

A similar process has then also affected banks. On the other hand, it has initiated operations of mergers at the end of the nineties. The Cassa di Risparmio of Calabria, as seen above, lags behind other Italian Casse di Risparmio. The problem of growth and affirmation in the perspective of the European market was addressed not only through concentration and takeover processes (even more complex for the Cassas considering the strong cultural roots also in the area), but also through organizational, procedural restructuring and technology, aimed at achieving economies of scale. The international horizon resulting from the creation of the European market has in fact imposed a strengthening of the quality of banking services, through the professionalism of staff, improvement of processes and products, upgrading of information systems, the adoption of techniques of analysis and segmentation of demand, adequate personnel management policies to the new economic environment, etc.. In general terms that historical moment demanded a not only operational but also cultural renewal to meet the strategic and organizational implications of the integration of the European banking market.

The Minister Carli 8 October 1988 on the occasion of the Credit day said: "Allow me to recall with nostalgia the past, now distant, when the Cassa was the Cassa di Risparmio: dialoguing with local administrators of school, hospital, police station; with farmers, artisans, merchants, in short, with the common people, who identified the institution as a friend and in whom they trust. Today, the manager of the Cassa before visiting sentinel office closures at the Tokyo and the Sydney Stock Exchange, negotiates with the leaders of large groups, making swaps, interest and exchange rates, trading options". It is also in this context that the Cassa di Risparmio of Calabria is particularly ineffective action.

\section{Conclusions}

The research aims to analyze the credit policies of a local bank situated in Calabria (South Italy) after unification, addressing the recent calls for a contextualized and interdisciplinary accounting history research. Following the distinction of the types of studies provided by Coronella, Antonelli and Lombrano (2017), our study can certainly be included in the field of "general histories, which examined the evolution of accounting practices from antiquity to the late nineteenth century". A previous study of Quattrone (2004) have already examined the accounting and accountability practices within the Society of Jesus from the sixteenth to the seventeenth centuries in Italy.

Our study refers to the of Cassa di Risparmio di Calabria, a local bank founded in Cosenza in 1861. In order to examine the credit policies we adapt Canergie and Napier's framework, which allows us to take into 
consideration also internal factors together with external factors.

The main results are summarized below: founded to stimulate the formation of savings among the lower classes of the population the role of the Cassas has deeply evolved depending largely on the economy of the country, in line with other lenders. Unlike these, however, recently the Cassas have a localized spatial structuring which normally falls within the boundaries of the municipality, the province, the region or at most two neighboring regions. While differing in relation to procedural aspects, the common denominator of the Cassa remains, besides the lack of profit motive, the geographical location of the jurisdiction of individual institutions, whose main advantage is the investment of savings, collected in the same benefit area the economy of those who have such a savings product (Titta, 1969). The relationship with the land is so narrow that the credit and financial policies affecting the local economy, and in turn demographic, economic and social dynamics and variables affect how the Cassa operates in that territory. The geographical location allows administrators to know the qualitative composition of the savings flowing to the Cassa. Family savings, corporate savings and public savings have specific characteristics and a different degree of mobility and flexibility, thus affecting the performance of loans. The knowledge of the territory allows a list of priorities in loans to be identified from the point of view of their importance for the community. The conscious assessment of local capital needs translates into a common benefit, both for the financing of public works and for that of small and medium enterprises that are most in need of financial support.

In essence, the presence of the Cassa in place contributing to the economic development of the area: the socio-economic structure of the territory affects the formation of the flow of collectable resources, the case of active intervention allows a propulsion force of the process economic operating environment itself (Titta, 1969).

The Cassa di Risparmio di Calabria has contributed to the elevation of the human condition of the territories under its jurisdiction, and assigned great importance to socio-educational investment. With regard to important economic investment, it offered major financial support to farmers, public institutions and the construction sector, while it has been of marginal support to the manufacturing and commercial activities. Our results are consistent with those found by Lazzini, Iacoviello and Ferraris Franceschi (2017), regarding the institutional and structural measures adopted by the State the 50 years after the unification of Italy.

Analyzing the policy of the Cassa, up to the sixties of last century, (as already seen), a tendency to hoarding can be detected, which in fact negated huge money supplies to useful investments (Acciaro, 1960). After the sixties, a timely response to the stimuli offered by the Europeanization process which also involved our country cannot be detected, and a political drift, (in a negative connotation of the term) a harbinger of efficiency and competitiveness losses.

In conclusion, we can see that the journalistic spirit that animated the Cassa has certainly contained the boost its activity geared toward competitive, which would involve more risk but that would have allowed the institute also to perform the function of the flywheel of the Calabrian economic system, of which there was certainly no need, the territory lacking private entrepreneurial economic initiative. As he remembered the undersecretary at the Ministry of the Treasury in 1970, the lawyer. Venturini Picardi, "Without savings there cannot be programmes and without investment there cannot be progress".

\section{Acknowledgments}

We would like to thank the Editors and the anonymous reviewer, for useful comments and suggestions whose improved the substance of the paper. Although the article is the result of the joint study of the authors, paragraphs 1 and 3 are attributable to Franco Ernesto Rubino, paragraphs 2, 4, 6 to Pina Puntillo and paragraph 5 to Domenico Rocco Cambrea.

\section{References}

Acciaro A. (1960). Le Casse di Risparmio nel Mezzogiorno in Il risparmio no. 8

Amaduzzi, A. (2001). Storia della Ragioneria. Uomini, aziende, contabilità, Collegio dei Ragionieri di Bergamo, Erba.

Amilcare, R. O. (1991). Cassa di risparmio di Calabria e di Lucania : una pagina di storia bancaria inesplorata, in Rassegna dell'economia lucana no. 1, Potenza

Amilcare, R. O. (1991). Dalla Cassa di risparmio di Calabria citeriore alla Cassa di risparmio di Calabria e di Lucania, in Economia catanzarese, no. 3

Ammannati, L. (1980). Note sul ruolo della Cassa per il Mezzogiorno, in Sviluppo : Rivista di studi e ricerche della Cassa di risparmio di Calabria e di Lucania, no. 23 (Apr.-Jun.) 
Antoniozzi, F., \& Conti, D. (1955). La politica degli sportelli bancari in Italia dal 1926 in poi, in Atti dell'VIII congresso delle Casse di Risparmio Italiane, Tipografia delle Terme, Rome

Bowen, G. A. (2009). Document analysis as a qualitative research method. Qualitative Research Journal, 9(2) 27-40. https://doi.org/10.3316/QRJ0902027

Butkiewicz, James L., \& Leo-Rey, C. G. (2013). The economic growth effect of offshore banking in host territories: Evidence from the Caribbean. World Development, 44, 165-179. https://doi.org/10.1016/j.worlddev.2012.09.017

Cardinali G., (1953). Appunti sulle Casse di Risparmio, Ed. Giuffrè, Milan

Cardinali, G. (1969). Problemi ed aspetti del mercato creditizio nell'ultimo quarto di secolo, Tomo IV, Categoria Casse di Risparmio, Milan

Cardinali, G. (1972). L'attività delle casse di risparmio e delle banche popolari nel contesto dell'economia nazionale, in Economia e credito no. 3

Carnegie, G. D. (2014). The present and future of accounting history. Accounting, Auditing \& Accountability Journal, 27(8), 1241-1249. https://doi.org/10.1108/AAAJ-05-2014-1715

Carnegie, G. D., \& Napier C. J. (1996). Critical and interpretive histories: insights into accounting's present and future through its past. Accounting, Auditing \& Accountability Journal, 9(3), 7-39. https://doi.org/10.1108/09513579610121956

Coronella, S., Valerio, A., \& Alessandro, L. (2017). A pioneering era of accounting history: The contributions of nineteenth-century Italian literature and its enduring dissemination around the globe. Accounting History, 22(2), 214-243. https://doi.org/10.1177/1032373216662486

Dell'Amore, G. (1953). La funzione delle Casse di Risparmio nel sistema bancario italiano, Milan

Dell'Amore, G. (1975). Passato, presente e futuro delle Casse di risparmio italiane, in Il risparmio no. 2.

Figuet, J. M., Humblot , T., \& Lahet, D. (2015). Cross-border banking claims on emerging countries: The Basel III Banking Reforms in a push and pull framework. Journal of International Financial Markets, Institutions \& Money, 34, 294-310. https://doi.org/10.1016/j.intfin.2014.11.016

Fink, G., Peter, H., \& Mina, V. (2007). Serbia's banking sector reform: implications for economic growth and financial development. Southeast European and Black Sea Studies, 7(4), 609-636. https://doi.org/10.1080/14683850701726096

Frasca, S. (1983). Una battaglia vinta: interventi e prese di posizione sulla Cassa di Risparmio di Calabria e Lucania, Rome.

Ghosh, A. (2017). How does banking sector globalization affect economic growth? International Review of Economics \& Finance, 48, 83-97. https://doi.org/10.1016/j.iref.2016.11.011

Hamdaoui, M. (2016). Are systemic banking crises in developed and developing countries predictable? Journal of Multinational Financial Management, 37-38, 114-138. https://doi.org/10.1016/j.mulfin.2016.09.002

Ho, S. Y., \& Odhiambo, N. M. (2013). Banking sector development and economic growth in Hong Kong: An empirical investigation. The International Business \& Economics Research Journal (Online), 12(5), 519. https://doi.org/10.19030/iber.v12i5.7827

Hopwood, A. G. (1983). On trying to study accounting in the contexts in which it operates. Accounting, Organizations and Society, 8(2/3), 287-305. https://doi.org/10.1016/0361-3682(83)90035-1

Jurakovaite, O. (2017). The evaluation of EU banking network regionalization in the global context during post-crisis period.

Khasanova, A. N., \& Adel, A. D. (2017). Modern trends in the development of the economy and banking system in conditions of new normal. QUID: Investigación, Ciencia y Tecnología, 1, 1303-1309.

Kim, D. (2015). Offshore Banking and Economic Growth: A Cross-Country Analysis. Global Economic Review, 44(3), 308-323. https://doi.org/10.1080/1226508X.2015.1072472

Kragh, H., \& Fanti, G. (1990). Introduzione alla storiografia della scienza. Zanichelli.

Lazzini, A., Giuseppina, I., \& Rosella, F. F. (2017). Evolution of accounting education in Italy, 1890-1935. Accounting History. https://doi.org/10.1177/1032373217715041

Martinez-Jaramillo, S., Alexandrova-Kabadjova, B., Bravo-Benitez, B., \& Solórzano-Margain, J. P. (2014). An 
empirical study of the Mexican banking system's network and its implications for systemic risk. Journal of Economic Dynamics \& Control, 40, 242-265.

Mathias, P. (1993). Business history and accounting history: a neighbourly relationship. Accounting, Business and Financial History, 3(3), 253-273. https://doi.org/10.1080/09585209300000052

Pawlowska, M. (2016). Does the size and market structure of the banking sector have an effect on the financial stability of the European Union? The Journal of Economic Asymmetries, 14, 112-127. https://doi.org/10.1016/j.jeca.2016.07.009

Philippas, D., Koutelidakis, Y., \& Leontitsis, A. (2015). Insights into European interbank network contagion. Managerial Finance, 41(8), 754-772 https://doi.org/10.1108/MF-03-2014-0095

Polimeno I. (1958). Caratteristiche di fondo e prospettive di sviluppo dell'economia italiana, Ed. Consulomnia, Rome.

Quattrone, P. (2004). Accounting for God: accounting and accountability practices in the Society of Jesus (Italy, XVI-XVII centuries). Accounting, Organizations and Society, 29(7), 647-683. https://doi.org/10.1016/j.aos.2004.03.001

Ryan, B., Scapens, R. W., \& Michael, T. (2002). Research method and methodology in finance and accounting. https://doi.org/10.1186/1687-6180-2011-78

Sabbatini M. (1984). L' intervento della Cassa per il Mezzogiorno ed i suoi effetti sull'agricoltura meridionale negli anni settanta : il caso della Calabria. in Sviluppo : rivista di studi e ricerche della Cassa di risparmio di Calabria e di Lucania, $n$. 38 .

Servalli, S. (2007). Il metodo e l'analisi sistemica nelle ricerche di Storia della Ragioneria. Contabilità e cultura aziendale, 7(2), 59-78.

The World Bank. (2017). Banking crisis. Retrieved from http://www.worldbank.org/en/publication/gfdr/background/banking

Titta A. (1969). Competenza territoriale delle casse di Risparmio, in Il Risparmio n. 1

Tonzer, L. (2015). Cross-border interbank networks, banking risk and contagion. Journal of Financial Stability, 18, 19-32. https://doi.org/10.1016/j.jfs.2015.02.002

Yin R. (2003). Case study research: Design and methods. Sage Publications, Inc. https://doi.org/10.1080/09500790.2011.582317

\section{Copyrights}

Copyright for this article is retained by the author(s), with first publication rights granted to the journal.

This is an open-access article distributed under the terms and conditions of the Creative Commons Attribution license (http://creativecommons.org/licenses/by/4.0/). 